\title{
Quranic Multiple Intelligences and its Implementation in Educational Institutions
}

\author{
M Husnaini ${ }^{*}$, Dawood Abdulmalek Yahya Al-Hidabi' ${ }^{2}$, Betania Kartika ${ }^{3}$, \\ Irnie Victorynie $^{4}$ (https://orcid.org/0000-0001-6765-6491, Ahmad Shidqi Mukhtasor ${ }^{5}$ \\ 1,2,3,4,5International Islamic University Malaysia, Malaysia \\ *e-mail: *hus surya06@yahoo.co.id
}

\begin{tabular}{l}
\multicolumn{1}{c}{ Article Information } \\
\hline Received: June 15, 2021 \\
Revised: August 21, 2021 \\
Accepted: August 20, 2021 \\
Online: September 22, 2021 \\
\hline \multicolumn{1}{c}{ Keywords } \\
\hline Intelligence, multiple intelligences, \\
Qur'anic multiple intelligences.
\end{tabular}

\section{INTRODUCTION}

In 1900, Alfred Binet, a France psychologist, found a human intelligence scale called IQ (intelligence quotient). Lots of people thus believe that an intelligent person is a person that has a high IQ level. However, in reality, not everyone with a high IQ level can adapt, socialize, control their emotions and spiritual tranquility. Many people with a high IQ level cannot get along with other people, socialize, and build exemplary communication skills. In other words, there are elements of intelligence that are beyond what Alfred Binet has found (Nugroho, 2004). Many people with a decent level of IQ but do not have the intelligence to do aspects of things that may constitute their success in the future, thus failing to map their priorities to work themselves towards success.

In contrast, other brilliant students playing music and sports were employed on several banks as permanent employees. In other cases, doctors who graduated in time (6-7 years) with Cumulative Grade-Point Average (CGPA) above 3,0 became failing doctors, who ended up at the head of public health centers or practical doctors at private hospitals. When becoming the head of the public health center, they fail to lead. When they open their practices, they lack patients. While their colleagues who were almost dropped out because of their exceeding study terms, with an average CGPA, became successful 
doctors when they worked within the community. Others even became leading doctors and role models (Pasiak, 2008).

IQ has monopolized the intelligence theory, where an individual's intelligence is only measured by a logic-systematic, quantitative, and linear intelligence. As a result, other aspects of human intelligence are neglected. In the practice of education, some indicators of the learning process that deviate from the essence of education are often found. Thomas Armstrong described a classic learning model in which raised presumptions on the current educational system. First, teachers tend to separate or classify their brilliant students and bad students on the other side. Second, the class environment is monotone and unengaging. The teachers only focus on one or two aspects of intelligence in teaching, linguistic and logical intelligence. Third, perhaps a teacher has difficulties arousing their students' desire to learn because their learning process is not creative enough (Armstrong, 2004).

The hegemony of IQ as the only intelligence theory cannot be taken away from its historical, scientific, and cultural background. Historically, IQ as an intelligence theory is indeed the first intelligence theory that has been around for 200 years and more, founded by Frenologi Gall. At that time, an intelligent person was only known through their high quality of IQ. In the early history of its development, the first methodology to measure intelligence was by knowing their IQ level. Galton, the cousin of Darwin, was the first person who thought about the possibility of measuring intelligence. What drove Galton to think of such was because Galton had always been interested in the differences of individuals and the relationship between heredity and mental capacity. According to Galton, two general qualities that could differentiate a more intelligent person from a less intelligent person are energy and sensitivity. An intelligent person, according to him, has a level of superior intelligence and sensitivity towards stimulations from their surroundings (Efendi, 2005).

Scientific research committed to the theory development of human intelligence thus kept being done by scientists, especially neuroscientists. The education world also needs renewal, or innovation, to be precise. Innovation is not only ideas, practices, and objects perceived as new, but it shall be different from their previous being. This difference is what constitutes a unique value within innovations (Suryana, 2009). Finally, Howard Gardner researched the field of human intelligence seriously for 20 years. He found the concept of multiple intelligences that emphasized bio-psychological potential and acted as a set of intelligent talents in the self of an individual (Hernowo \& Nurdin, 2004). Gardner's intelligence theory thus later be known as multiple intelligences, or MI theory, that a person's intelligence is plural rather than singular, even it may be unlimited. Gardner interpreted intelligence as the capacity to solve different problems, raise new problems to be solved, and create valuable innovation in a cultural environment or more within society (Gardner, 2013). The theory of multiple intelligences has broken the myth that an intelligent person is one with merely a high IQ level alone. Every individual in the view of multiple intelligences theory is bright because each individual in one's essence has a specific intelligence and potential that may differ from one another. Gardner called it a unique potential that will contribute to everyone's success in their learning process when cultivated correctly and appropriately. There are two essential aspects in multiple intelligences theory related to the definition of intelligence. The first is that not every student has the same interest, capacity, and learning method. Second, no student could be called inherently stupid because a person's capacity could not be measured by only one or two abilities (Hernowo \& Nurdin, 2004).

Now, Howard Gardner's finding has influenced many schools. Therefore, the theory of multiple intelligences has resulted in an approach of learning that gives students experiences that may help them develop and deploy all of their intelligence (Armstrong, 2004). The details of each intelligence that Howard Gardner has founded were popular through the book titled Frame of Mind that was published in 1983, where it was mentioned there that there are seven bits of intelligence. However, in 1999, through Intelligence Reframed, Howard Gardner said that in the self of an individual lies nine types of intelligence with the description as follows:

1. Linguistic intelligence. It is the ability to process thoughts in words or use language to express and appreciate the complex meaning of authors and poets.

2. Logical-mathematical intelligence. It is the ability to count, measure, consider propositions and hypotheses, and solve numerical problems, as scientists and accountants possess.

3. Spatial-visual intelligence. It is the sensitivity to explore imagination, modify the shade of an object, and transform variously aptly, as possessed by artists and sailors. 
4. Kinesthetic intelligence. It is the ability to move, turn, and control the body in a complex and specific movement, as possessed by athletes and dancers.

5. Musical intelligence. It is the sensitivity in understanding patterns of tones, melody, rhythm, and tempo, as possessed by singers and musicians.

6. Intrapersonal intelligence. It is the ability to understand and motivate themselves, thus acting upon those beliefs and understanding theologians and philosophers possess.

7. Interpersonal intelligence. It is the ability to understand thoughts, attitudes, behavior, and the will of other people, as possessed by counselors and politicians.

8. Naturalist intelligence. It is the sensitivity towards nature surrounding themselves by appreciating its beauty and the sense of care to preserve it, as possessed by astronauts and farmers.

9. Existentialist intelligence. It is the ability to build a strong awareness of life after death, as possessed by prophets and apostles.

These nine bits of intelligence mentioned above are the products of human's pure thought. As the perfect creature, human has the strong desire to always delve more profound upon life and its meaning, including upon themselves. With that being said, the people who believe in God (mu'minūn) are obliged to make the Quran the primary source of inspiration and references to ensure that no thoughts and pursuits are strayed (Ilyas, 2019). The Quran is the Holy Book in which functions as guidance (huda), testimony (bayyinah), and proof (furqān) for the believers (Wahid, 2011).

Suppose we believe that Allah has created the whole vast universe within, and by Him to the Quran was bestowed upon Prophet Muhammad for humankind's safety and prosperity. In that case, the answers to the world's problems cannot be absent from the explanations from the Quran. It is how we perceive the Quran and our willingness to uncover every answer within it consistently. If not, the Quran will forever only be an Arabic book that only is possessed, thus being read once in a while, and forever is kept in a shelf or a cabinet, forever without producing any pieces of knowledge. As the authors have previously analyzed the elements of multiple intelligences in the Quran (Husnaini et al., 2020), the authors will explore its development method through educational institutions.

With that being said, driving, the authors titled this article Quranic Multiple Intelligences and Its Implementation in Educational Institutions. The authors will analyze several issues needed to be answered in developing Quranic Multiple Intelligences through educational institutions. First, how to develop Quranic Multiple Intelligences through the spiritual approach? Second, how to develop Quranic Multiple Intelligences in its practical manner? The authors brought these two research questions to provide this article with good detail in developing Quranic Multiple Intelligences through educational institutions. The authors hope that this article may contribute to the development of the educational world in its actuality and renew the multiple intelligences concept with groundings derived from the Quran.

\section{METHODS}

This research type is library research, which is research through written materials as its analysis unit (Nata, 2002), in this case, the Quran. Data acquired thus is analyzed qualitatively, in descriptive written data (Moleong, 2003). In other words, this research does not use numbers but words and sentences ( $\mathrm{Hadi}, 1995)$. Qualitative descriptive research also portrays the object related to the problem researched without troubling the relationship between research variables (Faisol, 1992). While in the other hand, the approach used in this approach is thematic tafsir (maudiú $i$ ). This method derives the attention towards a chosen topic, thus finding the Quran's views on the topic by collective all verses ( $\bar{a} y \bar{a} t$ ), complemented by hadith, to formulate a conclusion holistically and thoroughly on the discussed topic (Shihab, 2013). The thematic method consists of two forms. First is thematic tafsir by thoroughly discussing one chapter (sürah) of the Quran and explaining the general meanings contained by correlating verses and various issues in one chapter. The second form is thematic tafsir by gathering and arranging all the verses with the same intention, thus analyzing it from various aspects to layout the product of tafsir into the chosen topic (Baharuddin, 2007). By referring to the illustration on the tafsir method mentioned, the tafsir method aligned with the research object and objectives is the second type of the tafsir method. Some steps should be done in implementing thematic tafsir , according to $\underline{M}$. Quraish Shihab (2013), as follows: 
1. Decide the topic that will be analyzed.

2. Trace and gather issues discussed through the collection of Quranic verses that talked about the topic.

3. Study the collected verses that discussed the chosen topic by understanding the cause of the revelation (asbāb an-nuzūl).

4. Arrange the sequence of the respective verses with the correlating cause of revelation, primarily if it is related with the law $(h u k m)$, or the chronology if it is related with a story until the phenomenon is portrayed from it the beginning to the end.

5. Understand the correlation (munāsabah) from the verses with the respective chapters.

6. Arrange the discussion in a systematic and integral outline.

7. Complete the explanation of the verses with hadīth, narrations from the companions (shahāabah), and others that may be relevant to complete the discussion into clarity.

8. After the whole content of the verses discussed has been portrayed, the next step is to gather each verse into a group of analyzed verses by putting aside those which have been represented, or to compromise between the general ('ām) and the specific (khāss), muțlaq and muqayyad, or when there is a contradiction, thus all are gathered in one compilation without differentiation nor force, thus raised the conclusion of the Quranic view on the topic chosen.

As mentioned before, this article is library research. Thus, the data is acquired from written materials. The primary source of this research is the Quran because the analysis unit is valid, the Quran, and the copies used by the authors as the references are:

1. Al-Quran dan Terjemahnya, The Ministry of Religion of the Republic of Indonesia and the Government of Saudi Arabia, nd.

2. Muhammad Thalib, Al-Quran Tarjamah Tafsiriyah: Memahami Makna Al-Quran Lebih Mudah, Cepat, dan Tepat, Yogyakarta: Penerbit Ma'had An-Nabawy, 2012.

Aligned with the steps taken in the thematic tafsir method, the authors went through three steps of analysis technique (Munawwar-Rachman, 1995). First, by choosing critical terms from the vocabulary of the Quran that explains intelligence. Second, by interpreting the basic meaning and relational meaning (ma'na nasabi), the primary meaning is earned through research on several dictionaries that study the meaning of those vocabularies. In contrast, relational meaning, a complementary meaning of the term, is related to the context of the sentence where the vocabulary lies within, acquired through the opinions from scholars and tafsir experts. Third, to conclude and to find hidden meaning from the concepts acquired. In this step, the reflective and interpretative paradigm is utilized. Interpretative paradigm is an attempt to grasp the essence from the literal and to find hidden essence from what is implied by the verses and concepts from the Quran, by relating it with aspects related which by its character is either logical-theoretical, ethical, or transcendental (Muhadjir, 2000). While on the other hand, the reflective paradigm is the continuation of the interpretative paradigm. This paradigm is conducted within the Quranic texts and the research towards theories from Muslim's intellectual heritage to be used as a supporting instrument to understand meanings and essences that lie within verses of the Quran, not by appropriating the verses to comply with the existing theories by those scholars (Baharuddin, 2007).

Using these techniques is expected to describe the development of multiple intelligences of the Quran through the world of education.

\section{RESULTS AND DISCUSSION}

Humankind has been granted the chance to live in this world with all of its complexity. That is one of the reasons why they are provided with intellect by Allah so they may always fight for the sustenance of their lives, solve their problems, and the most important is to give the meaning of their existence. Since its first creation, humankind has been bestowed knowledge before anything else, as revealed in the Quran.

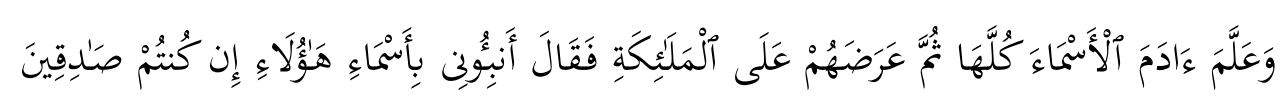

"He taught Adam the names of all things, then He presented them to the angels and said, "Tell Me the names of these, if what you say is true?" (QS Al-Baqarāh: 31) 
The Quran has also explained explicitly that Allah has granted humankind the capacity of intellect.

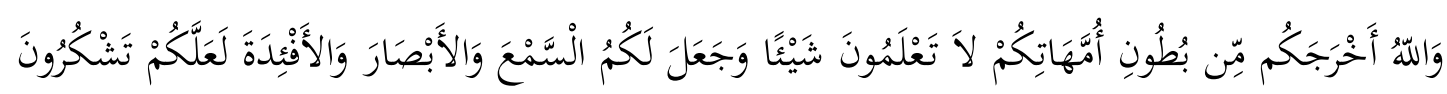

"And Allah brought you out of the wombs of your mothers while you knew nothing, and gave you hearing, sight, and intellect so perhaps you would be thankful." (QS An-Nahl: 78)

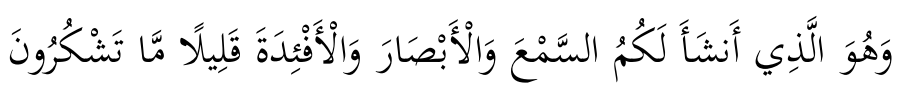

"He is the One Who created for you hearing, sight, and intellect. (Yet) you hardly give any thanks." (QS Al-Mu'minun: 78)

In other verse, there is even a strong prohibition for humankind to not act without any knowledge.

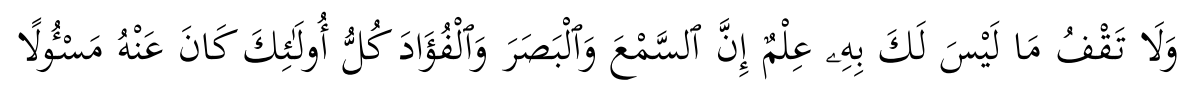

"Do not follow what you have no (sure) knowledge of. Indeed, all will be called to account for (their) hearing, sight, and intellect." (QS Al-Isra: 36)

In this complex world where humankind lives as a social creature, a set of abilities to cooperate and solve issues relating to themselves and others is highly needed. One type of intelligence would not be sufficient to fulfill the need; indeed, humankind requires multiple intelligences. Moreover, possessing intellectual ability does not assure a better quality of faith and spiritual values. It has been proved that many intelligent people would not believe in Allah. According to Nasaruddin Umar, the verse implies that intellectual intelligence is sometimes used to legitimate disbelief, where intellectual intelligence should be used to achieve higher intelligence. A wise scientist would not stop themselves at the degree of intellectualism, but they will synergize it with other higher intelligence (Republika, 2009). With that being said, as previously mentioned, Gardner has come up with multiple intelligences as the capacity to produce innovations with creativity values, including problem-solving independently. It is why it is essential to implement it in educational institutions.

Multiple intelligences saw as has prepared students with a reliable and quality of character. Through multiple intelligences, tedious learning processes become fun. Besides that, students learn that the theories taught are also actual in their real life and even directly experience, thus molding an even deeper understanding. It shall be acknowledged that many students have the capacity of other intelligence, such as sports, arts, music, and more. Because of that, the implementation of multiple intelligences in education may save a student from the confined education system in logicalmathematical-linguistical intelligence alone. After understanding multiple intelligences, thus it is in its logical consequence to demonstrate that intelligence brings benefits for the livelihood of the world as a whole. Not only for humankind but as well for nature and everything within. Related to this, educational institution, in other words, has the primary task to develop that intelligence. Thus, it may grow and develop within the self of the students, thus caused a positive influence on the students' surrounding environment.

In general, fundamental, and decisive, the intention of the Quran's descent is also to enlighten humankind; thus, humankind may live within His guidance. Related to this, the authors would like to stress that to cultivate and develop intelligence, it shall be started through a spiritual approach. Other than that, intelligence that is not guided by spiritual values has made humankind dazzled and obsessed with their power, thus underestimating Allah's power, which resulted in them being in misery and cause harm to others. The authors will explain the steps that educational institutions should do in developing multiple intelligences based on the concept that the authors found through the Quran: 


\section{Developing Quranic Multiple intelligences through Spiritual Approach}

The authors put this approach at the first part of our educational approach because all this time, intelligence is only understood as related with their smartness and intellectual aspect only, and seldomly related with the spiritual aspect. Acknowledged or not, the Quran itself has not been used as a reference often enough to cultivate and develop human intelligence's potential.

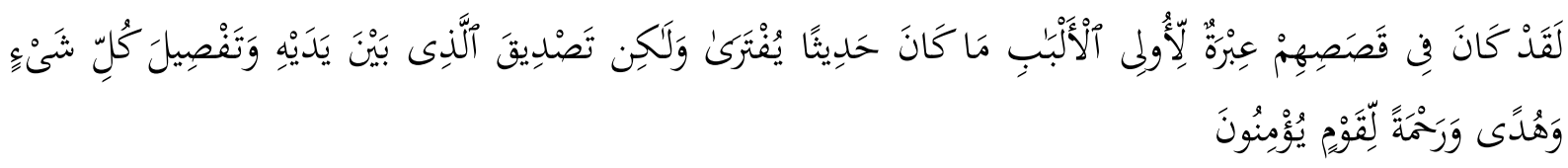

"In their stories, there is truly a lesson for people of reason. This message cannot be a fabrication, rather (it is) a confirmation of previous revelation, a detailed explanation of all things, a guide, and a mercy for people of faith. "(QS Yūsuf: 111)

The followings are the steps that should be taken by educational institutions and to be implemented towards their students:

\section{Strengthening their faithfulness (īmān)}

Faithfulness is the first and foremost principle that humankind shall possess if they want to acquire the blessings promised by Allah. This principle shall be fulfilled because it will give a continuous influence in studying, understanding, and practicing the values of the Quran, which is spiritual, consistent, and thorough.

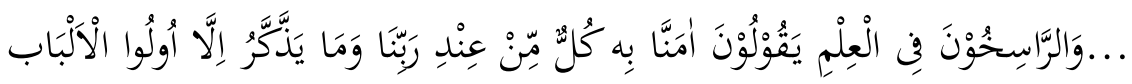

"As for those well-grounded in knowledge, they say, "We believe in this (Quran)-it is all from our Lord." But none will be mindful (of this) except people of reason. (QS Ali 'Imrān: 7)

Faithfulness is a binding rope that has the power to find guidance in our various life challenges to attain Allah's blessing. It is also an absolute parameter in deciding how far, how big, how deep, and how many are the essence of practices that may be categorized as the proof of man's servitude towards Allah. Among essential activities that are possible to be implemented by educational institutions to develop student's intelligence through faithfulness approach are as follows:

a. To push and give a role model to the students to make them get used to reading the Quran, followed by a strong desire to understand and contemplate its meaning, thus communicating with the Quran, to the extent to practice the Quran thoroughly in their daily life.

b. To arrange programs and agendas that may strengthen the bond between the students with mosque, through obligatory șalātjamā'ah in Masjid, learning circles, and social activities.

c. To train and control students in their sunnah rituals continuously and adequately.

d. To explain the students on the issue of shubhāt, especially some that clearly haram so that those practices could be hindered in their daily lives.

e. To accustom students to do good and encouraged practices, even though it is simple and not much like greeting others, maintaining a good relationship, and even smiling as a decent person towards others.

2. Strengthening their piety ( $\operatorname{taqw} \bar{a})$

In a broader sense, piety/taqwā is self-control or delaying pleasures that are current or momentary to get true happiness, namely spiritual happiness (Madjid, 2007). It is also a form of attitude to always restrain an individual from the punishment by Allah by following His commandments and avoiding His prohibition (Ilyas, 2020). Taqwā is a way to show a servant's faith in God. Its shape is similar to attitude, but its embodiment has a lot to do with many activities. Taqwā is a representation of all the nature, behavior, actions, and effects of the existence of a believer. Allah insists that taqwā is an attitude that humans must possess. 


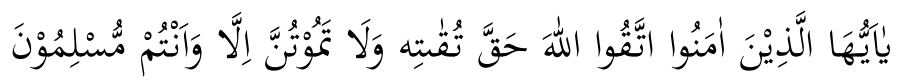

"O believers! Be mindful of Allah in the way He deserves, and do not die except in (a state of full) submission (to Him)." (QS Ali 'Imrān: 102)

The above verse insists on why Allah commanded the believers to have taqwā. The muttaqin (people who restrain themselves) is bestowed on those who have achieved the decree of taqwā. This decree is the highest decree for Allah, and no one could know the quality of one's taqwa but Allah Himself. Taqwā could be put as one of the attempts to bring the potential of human intelligence. Because of that, the educational institutions need to mold their students to become individuals with the personality of a muttaqin. The followings are some efforts that shall be done to mold taqwa within students:

a. To cultivate within the students their faith ( $\bar{i} m \bar{a} n)$ on the matters of the unseen $\left(g h \bar{a}^{\prime} i b\right)$, to do prayers (salāt), to do charity (infāq) with the provision provided by Allah, to believe in the Holy Book and the Day of Judgment, thus, to attain guidance from Allah and to be the people of fortune. It is aligned with the message in the chapter (sürah) Al-Baqarāh: 2-5.

b. To train students to learn a lesson from the stories of the disobedient people of the past. It is by the message from chapter Al-Baqarāh: 66.

c. To accustom students in hastening their repentance towards Allah when they make sins or mistakes. It is aligned with the message from chapter Ali 'Imrān: 133.

d. To guide students to believe in Allah, Day of Judgment, angels, Holy Books, prophets, give charities to the rightful, do prayers, give alms, hold their covenants, and be patient in adversity, suffering, and war. It is by the message in chapter Al-Baqarāh: 177.

e. To train students' passion for doing charity whenever possible, whether in ease or hardship, restrain anger, and forgive others. It is aligned with the message in chapter Ali 'Imrān: 134.

f. To train students in being assertive towards the non-believers (ka fir). It is according to the message chapter At-Tawbah: 123.

g. To encourage students to be content with the Quran. It is as in the message of chapter Maryam: 97.

h. To mold students' personalities to be humble and obedient towards Allah to close their life chapter with good reports. It is according to the message of chapter Al-Qașaș: 83.

i. To accustom students to their obligation to avoid immoral acts. It is according to the message of chapter Șad: 28.

j. To accustom students to do good deeds, lessen their sleep at night (to pray), ask forgiveness in the middle of the night, and spare their fortune for the rightful poor. It is by the message in chapter AdzDzāriyāt: 16-19.

k. To encourage students always to love the truth and to approve of it. It is by the message of chapter Az-Zumār: 33.

\section{Strengthening their prayers}

Prayer is a form of servitude process toward Allah. By reciting the supplications, a man may be connected with Allah. Other than that, prayers are also an expression of the longing feeling of a man towards Allah. Humankind, with all of its power, is also full of flaws. With that, prayers portray humankind's incapacity and servitude towards Allah, with their wills and need to be hoped to be fulfilled by Allah.

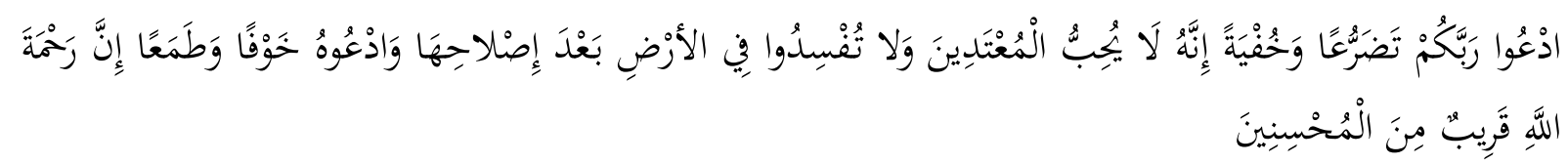

"Call upon your Lord humbly and secretly. Surely, He does not like the transgressors. Do not spread corruption in the land after it has been set in order. And call upon Him with hope and fear. Indeed, Allah's mercy is always close to the good-doers." (QS Al-A'rāf: 55-56) 
In regards to the attempt to empower intelligence, the educational institutions shall impose several activities for their students which are related to praying, as the followings:

a. To cultivate the understanding to the students to always avoid everything forbidden by Allah, whether those are foods, deeds, so their prayers may be granted.

b. To give knowledge to the students on the essence of prayers that they deliver to Allah. With that so, when their prayers are granted, they will be grateful. Otherwise, they will not feel disappointed and lose hope when their prayers are yet to be fulfilled.

c. According to Islam, train them to pray with etiquettes (ādab) and norms, such as preserving their body's purity, clear thoughts, pure heart, and pure soul.

d. To accustom students to prioritize prayers' words and sentences that Rasulullah has exemplified. However, if they use their own words, they shall express their humility, inability, and sincerity.

\section{Accustoming them to remembrances and contemplations (dzikr)}

In the Quran, there have been found many reasons related to the importance to remember Allah, such as for an individual to be remembered by Allah (QS Al-Baqarah: 152), to avoid calamities (QS AzZumār: 22), to tranquil the heart (QS Ar-Ra'du: 28), to soften the heart (QS Al-Hadid: 16), not to be in loss (QS Al-Munāfiqūn: 9), to be protected from vileness and disobedience (QS Al-Ankabūt: 45), to be able to call out the seduction of the devil (QS Al-A'rāf: 201). The importance of $d z i k r$ also been mentioned in various narrations of hadith, where its main purpose is to help an individual be closer to Allah (taqarrub) (Yasin, 2014). Dzikr is also seen as an excellent attempt to develop the intelligence of humankind; it is by doing dzikr as many as one could according to their capacity.

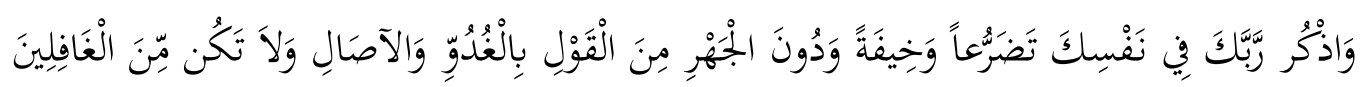

"Remember your Lord inwardly with humility and reverence and in a moderate tone of voice, both morning and evening. And do not be one of the heedless." (QS Al-A'rāf: 205)

There are several methods relating to $d z i k r$ that the educational institutions should implement to develop intelligence as the followings:

a. To accustom $d z i k r$ for students, and to cultivate inside themselves that $d z i k r$ is not only limited from reciting words and purifying one's heart but also that it shall be manifested in their soul and their practices, thus that their dzikr could be appreciated as their bridge that may connect them with Allah.

b. To train students to be passionate about doing dzikr in every time, situation, and condition.

c. To condition the students in upholding dzikr as exemplified by Rasulullah every after the five compulsory prayers.

d. To understand the students that regular dzikr may ease every affair, make one's life be in blessing, and open the possibility for one to be in husnul khātimah when they leave this world.

\section{Developing Quranic Multiple Intelligences through Practical Approach}

After explaining the attempts to develop intelligence through a spiritual approach, the practical ('amaliah) approach is next. This approach cannot be neglected at all. In other understanding, spiritual and practical approaches shall come hand in hand, practices simultaneously. Of course, the efforts shall be in line with the teaching of Rasulullah (PBUH/SAW). Because, as Qur'änan 'Arabiyan, or the Arabic reading, the Quran contains at least four functions: (1) so that humankind uses their intellect, (2), so that humankind become muttaqin, (3) stimulated to learn knowledge, and (4) to be the warning and cautions ( $\underline{\text { Sensa, 2005). }}$.

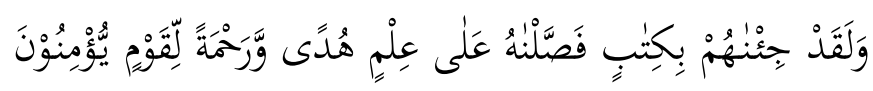

"We have certainly brought them a Book which We explained with knowledge-a guide and mercy for those who believe." (QS Al-A'rāf: 52)

Practices that the educational institutions could do to develop intelligence are as the following: 


\section{Championing the Quran}

Allah bestows the Quran for humankind with specific intentions and objectives. All of those are to give prosperity for humankind in their livelihood in the world today and in their afterlife. Championing the Quran could also be said to do jihād (strive) with the Quran. The implementation of jihād with the Quran could be done by the foremost, reading and understanding the Quran, thus depicting a vision that derived by faith ( $\bar{\imath} m \bar{a} n$ ) and taqwā to manifest practically the values of the Quran in daily life.

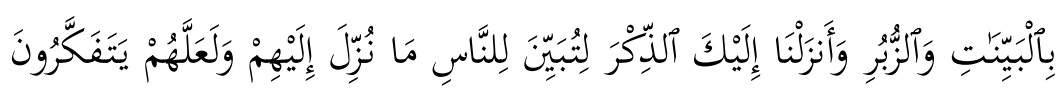

"(We sent them) with clear proofs and divine Books. And We have sent down to you (O Prophet) the Reminder, so that you may explain to people what has been revealed for them, and perhaps they will reflect." (QS An-Nahl: 44)

While the characteristics, types, and methods that could be done by educational institutions that could be categorized as a jihād with the Quran, are as follows:

a. To ensure there is the Quran with translation in the educational institutions. It means that it shall be followed by encouraging the students through several activities to actively read the Quran and understand the meaning through those translations.

b. To give explanations on the verses of the Quran as well as its proofs (bayān), tafsìr, and ta'wìl to the students, by the competent teachers, for the contains of the the Quran may touch the broad scope of every living aspect of the students.

c. To implement the values in the Quran into detailed aspects thoroughly by structuring concepts that could be laid out practically to be implemented by the students in real life.

d. To accustom students to use materials or theories from the Quran as their primary references when faced with otherworldly concepts or arguments.

e. To cultivate within the students the strong passion for implementing the values of the Quran in their daily life.

f. To equip students with resilience in striving for the values of the Quran consistently and responsibly.

\section{Practicing Prayers (Șalat)}

Salat is the obligation that would be felt heavy to be done. However, after it is done correctly and its essence and benefits are being understood, it will be easy to be practiced. Salat thus becomes the need that could not be neglected. Salat is not only an attempt to remember Allah (dzikr), but it is also a system that makes everyone who does it consistently and correctly attain the power to protect themselves from negative influences such as wicked and disobedience acts. Salat is also the primary key to solving complex and exhausting issues surrounding the life of humankind.

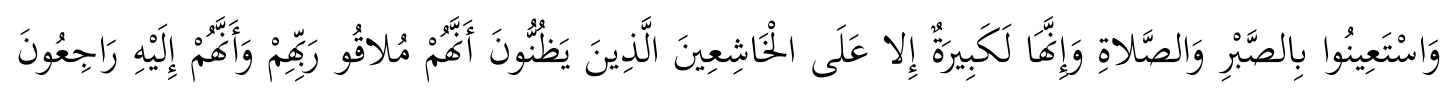

"And seek help through patience and prayer. Indeed, it is a burden except for the humble, those who are certain that they will meet their Lord and to Him they will return. " (QS Al-Baqarāh: 45-46)

To mold students who are passionate about loving and enjoying communal prayers (șalat jamā'ah) in the mosque, the educational institutions shall cultivate strong understanding within the students that salat may do the followings:

a. Salat could make oneself always feel close with Allah because they always build positive communication with Allah while keeping humble in the face of His Might.

b. Salat could bring incomparable happiness to those who practice it because Allah gives their problems and hardships the best solution.

c. Salat could cultivate the understanding and strong determination that Allah could be felt and sensed through tranquility within proper and consistent worship. 
d. Salat that is being done correctly, properly, willingly, and consistently will give a high level of personality in every aspect of living.

e. By delving meanings from the recitations and movements of șalat, humankind may thoroughly enhance their intelligence processed through self-purification.

\section{Practicing fasting}

Fasting, in a glance, is an activity that emphasizes the act of rendering oneself from eating, drinking, and doing a sexual activity from dawn until dusk. It is not limited to abstaining from those mentioned activities because if the only essence of fasting is as such, we would be trapped in the physical dimension of fasting. While at the same time, much research on fasting has approved that fasting is an activity that involves physical, emotional, and spiritual dimensions all at once. Alternatively, in simpler words, fasting is an activity that affects the mind and the body. With fasting, one can conduct activities starting from spiritual intentions, controlling themselves from various practices, including eating, drinking, sexual activity, and increasing communication with Allah (Mustofa, 2004). In the Quranic verse that contains Allah's command to the believers to practice fasting, the purpose has been mentioned, to make oneself being muttaqin.

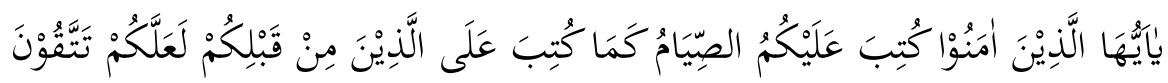

"O believers! Fasting is prescribed for you-as it was for those before you ${ }^{1}$-so perhaps you will become mindful (of Allah)." (QS Al-Baqarāh: 183)

Taqwā is a vertical dimension of living piously. In the Quran, it has been explained that the characteristics of pious people believe in the unseen, practicing salat, sparing their wealth for charity, believing the teachings of Muhammad and those before him, and believing in the Day of Judgement.

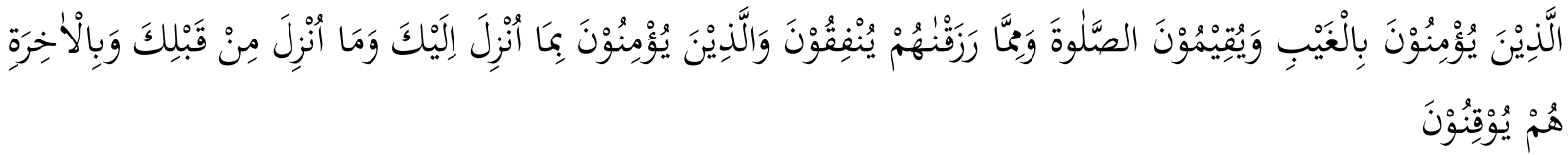

"Who believe in the unseen, establish prayer, and donate from what We have provided for them, and who believe in what has been revealed to you (O Prophet) and what was revealed before you, and have sure faith in the Hereafter." (QS Al-Baqarāh: 3-4)

Therefore, the implication of fasting is not only physical aspects of it, but the most important is when one practices the fasting command correctly and adequately, it will lead its doer into a spiritual treatment, and this is very valuable for the prosperity of humankind itself (Madjid, 2007). It shows that fasting is not a form of self-torture because the practice is enjoyable and straightforward to be done. In its relation to developing intelligence of the students, it could be done through accustoming fasting by cultivating the understanding that:

a. Fasting may result in humankind having a high awareness of Allah, that He is always accompanying themselves, resulting in them being cautious and aware with every one of their thoughts, words, and actions.

b. By fasting, it gives the possibility for humankind to introspect and to contemplate themselves by decreasing their bodily consumptions, resulting in suppressing lust domination for the purification of self

c. Fasting may make humankind ignore the seduce of lust and stress the empowerment of rational thoughts, inner soul, and truthful voices.

d. Fasting may train humankind to have solid physical durability by regularly regulating their diet while blindly devouring feasts. 


\section{Sparing charities from their fortunes}

The enjoyment that is the easiest to recognize and feel of its benefits directly is wealth. Due to this, wealth may become the means to cultivate sins and the instrument to attain self-purification. It depends on how one utilizes it. One of the living facts is that there is no similarity of wealth within humankind all over the world. To attain equality for humankind, Islam has obligated charity to those rightful for so. Not only to purify one's wealth but also to cultivate kinship within humankind and build the power of the ummah.

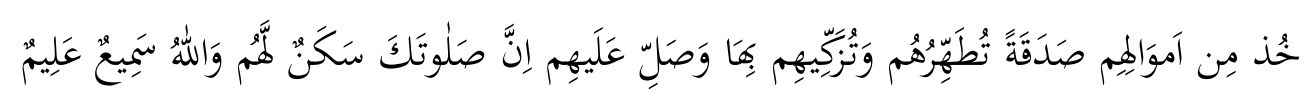

"Take from their wealth (O Prophet) charity to purify and bless them and pray for them-surely your prayer is a source of comfort for them. And Allah is All-Hearing, All-Knowing." (QS At-Tawbah: 103)

In the context of education, intelligence could be developed through the passion for giving charity. Educational institutions should always give the awareness to the student on the importance to purify their wealth by doing charity, alms, and so forth, that:

a. Within the wealth of humankind, there are rights of specific communities that should be passed on to make others feel the same enjoyment, though in different amounts.

b. Sharing wealth may strengthen communication and association within humankind, thus forming a structure and society that embraces love.

c. The custom of sharing wealth may build the bonding power with the spiritual and divine essence to empower ummah as the reflection of ummatan wasațan (moderate people) and khairah ummah (the best people).

\section{Prospering the Mosque}

The mosque symbolizes Allah's shrine on the earth and the best place to visit the believers. Through mosques, they actively communicate with Allah and do activities related to rituals, social, and education to empower their community to face daily challenges and fulfill the community's basic needs (Siskawati, 2016). Thus, the educational institutions shall encourage and create the generations who love and are passionate to serve their mosques. The prospering mosque is one of the characteristics of believers that is always in His guidance.

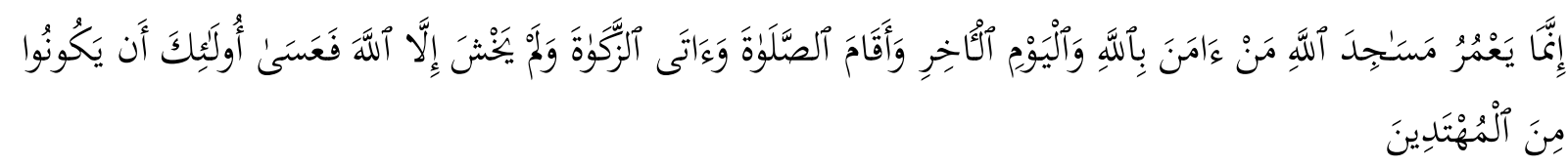

"The mosques of Allah should only be maintained by those who believe in Allah and the Last Day, establish prayer, pay alms-tax, and fear none but Allah. It is right to hope that they will be among the (truly) guided." (QS At-Tawbah: 18)

Consequently, the educational institutions shall cultivate within students the love towards mosques. Prospering mosques will also lead to enjoyments, such as:

a. To attain the highest tranquility, by being accustomed in only fear to Allah, purifying His Names, and not associating Him with anything else.

b. To accustom oneself with the characteristics of divinity, thus may strengthen the longing feeling for Allah and the feeling to always wanted to be living with Allah's existence.

c. To train oneself to always be in His path and moving towards Allah alone in the world lived. Even though they may enjoy materialistic enjoyment in one's own house, it would not hold them from going into mosques.

d. To try to be with the people who purify themselves and those who only orient themselves to Allah. Attitude as such will protect them from the tricks of the devil. 


\section{6. $\quad$ Living up the night (with prayers)}

Nighttime is the most enjoyable time for humankind to sleep. Nevertheless, even so, nighttime is also the best time to contemplate and to pray to Allah. At that time, humans may strengthen their intimate relationship with Allah. Related to their closeness with Allah, of course, it is not meant as something that can be acquired without any effort. The popular süfis declare that the relationship between an individual and Allah is enjoyable, a relationship that is longed for and belongs. Furthermore, that relationship will be felt reciprocal between Allah and His servant (Madjid, 2007). Because of that, praying at the end of the night is very much encouraged.

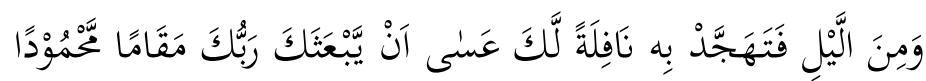

"And rise at (the last) part of the night, offering additional prayers, so your Lord may raise you to a station of praise. "(QS Al-Isrā: 79)

Besides, the end of the night has a rich amount of natural power that helps humans in their activities. It is seldomly utilized, compared with the daytime that many people are awake and maximize its potential. Nighttime is also the potential to hone one's intelligence to those who use it for doing worship and delving into knowledge. The educational institutions should always encourage and accustom students to passionately live their nights with worships and learning. The followings are the enjoyment in living the end of the night that could be socialized towards the students, which are:

a. The night's end gives many chances to dialogue directly with Allah, satisfy one's love and belonging to Him, and express themselves fully.

b. The inner power at the end of the night is very potential to hone self's positive potential to build a better and a successful living.

c. By living the end of the night, the worship activities could improve qualitatively and quantitatively.

\section{Studying}

Islam has concerned this activity very much, where the Quran is a comprehensive system that contains huge of educational texts that needed to be pondered upon (Arif, 2021). It is said that studying science and knowledge is one of the obligations. In this life, science is an instrument to ease and help humankind express their goals, especially to know Allah, thus surrendering themselves to Him. Science and knowledge are fundamental, especially for worshipping in which should be based on those.

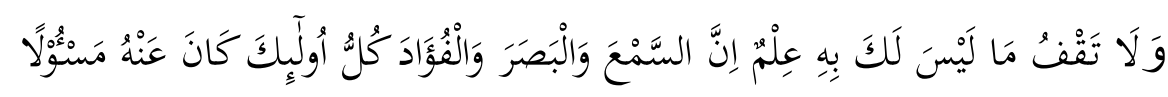

"Do not follow what you have no (sure) knowledge of. Indeed, all will be called to account for (their) hearing, sight, and intellect." (QS Al-Isrā: 36)

To do so, the educational institutions' primary goals are to teach lessons, knowledge, and science to their students. The followings are the impact that is caused by studying and learning process, which are:

a. Knowledge may free oneself from the confinement that blind humans from fully operating their physics, senses, mind, intellect, heart, and soul.

b. With knowledge, humankind could decide or choose within values in the world, good and bad, true and false, proper and indecent; thus, they would not be tricked by temporary pleasures.

c. The possession of knowledge allows oneself to do beneficial activities related to understanding and fulfilling the needs of individuals and the need of humankind in general.

d. By mastering science and knowledge, humankind can create works of living and build civilization.

\section{Doing good deeds}

Goodness (al-khair) is something that comes from Allah to be enjoyed by all beings in every kind of its forms (Arif et al., 2021). Several verses mention the types of al-khair, among others the gift of Allah given to His servants (QS Yūnus: 107), eliminating some of the errors (QS Al-Baqarāh: 271). Whoever is 
pleased to accept and spread al-khair in several ways and various measures, he will find the meaning and essence of life.

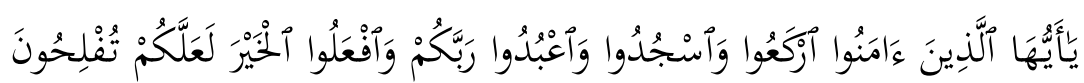

"O believers! Bow down, prostrate yourselves, worship your Lord, and do (what is) good so that you may be successful. "(QS Al-Ḥāji: 77)

Consequently, educational institutions need to motivate students to do and to spread al-khair. The educational institutions shall give understanding to their students that doing al-khair will bring many enjoyments, such as:

a. Actively practicing and spreading al-khair means to act as the vicegerent (khalifah) on the earth to manifest values bestowed by Allah to create prosperity for humankind and the universe.

b. Calling to al-khair may create collective awareness for all humankind that they could not only rely on their own and their loved ones' capabilities. Every success and failure could not be separated from the power of Allah.

c. Al-khair may give meaningful colors to the complex condition of the world to be more calming, beautiful, and content, thus giving the strong spirit of optimism.

\section{Practicing an educational trip (rihlah 'ilmiah)}

The educational trip is essential to encourage people to be active. All humankind has been granted the task to practice activities, so the others and the universe could benefit from their existence. Before doing some practices, they shall have the equipment and prerequisites by having data, information, and facts that their activities will be planned and executed. The acquirement of that equipment mostly is through their voyage in seeking knowledge. In the Quran, those things are depicted beautifully through the story of Prophet Mūsā that travels so far to learn from Khidīr.

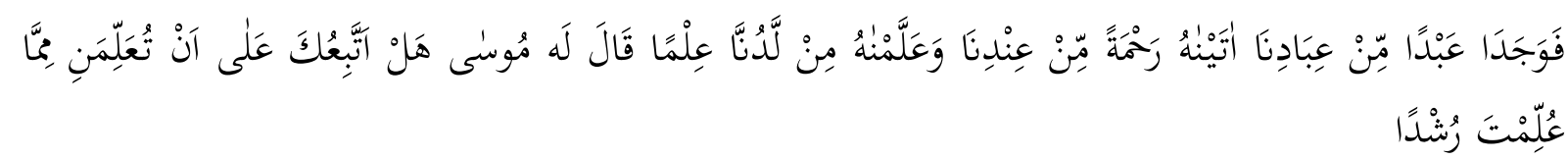

"There they found a servant of Ours, to whom We had granted mercy from Us and enlightened with the knowledge of Our Own. Moses said to him, "May I follow you, provided that you teach me some of the right guidance you have been taught?" (QS Al-Kahfi: 65-66)

In that context, an educational trip or journey should be meant as one of the means to acquire provision, and they shall be directed to acquire sufficient data, information, and facts that in the scope of:

a. To seek and understand history becomes a valuable lesson to build oneself, their family, and their community.

b. To know the figures of history that could be exemplified in behaving, acting, and directing the lives of humanity to attain progress and glory.

c. To understand the people's needs that should be fulfilled for their prosperity that may give tranquility to them and improve their faith and piousness, which lead to the blessings.

d. To empower one's soul, thus be able to guide the usage of intellect and senses that may produce activities, innovations, and impact by the Will of Allah.

10. Practicing pilgrimage (ḥâjj)

Pilgrimage ( $h \bar{a} \bar{j} j$ ) is one of the worship systems that has the meaning, message, and essence from the holy call to enjoy the love and blessing from Allah, where people from different tribes and races meet and understand each other the whole ummah. Rasulullah also has stressed its importance for Muslims who are capable in practicing it, that neglecting its practice while capable of it is deeply condemned and seen metaphorically to be better passed away as Christian or Jew rather than being a Muslim (Kisworo, 
2017). Therefore, educational institutions should motivate their students to have a strong passion for practicing pilgrimage.

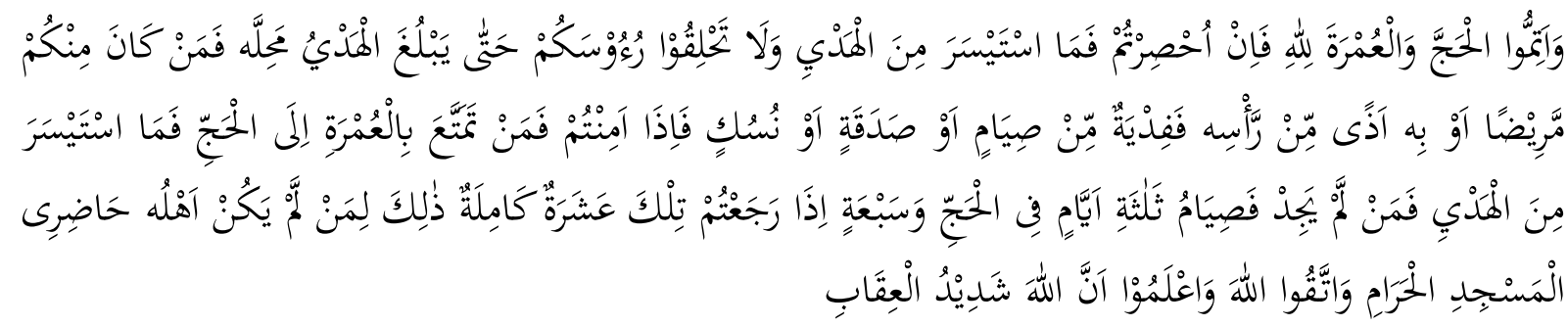

"Complete the pilgrimage and minor pilgrimage for Allah. But if prevented (from proceeding), then (offer) whatever sacrificial animals you can afford. And do not shave your heads until the sacrificial animal reaches its destination. But if any of you is ill or has a scalp ailment (requiring shaving), then compensate either by fasting, charity, or a sacrificial offering. In times of peace, you may combine the pilgrimage and minor pilgrimage, then make the sacrificial offering you can afford. Whoever cannot afford that (offering), let them fast three days during the pilgrimage and seven after returning (home)-completing ten. These offerings are for those who do not live near the Sacred House. And be mindful of Allah, and know that Allah is severe in punishment." (QS Al-Baqarah: 196)

In other verses, Allah also said firmly that Muslims should practice pilgrimage as the highest Islamic principle.

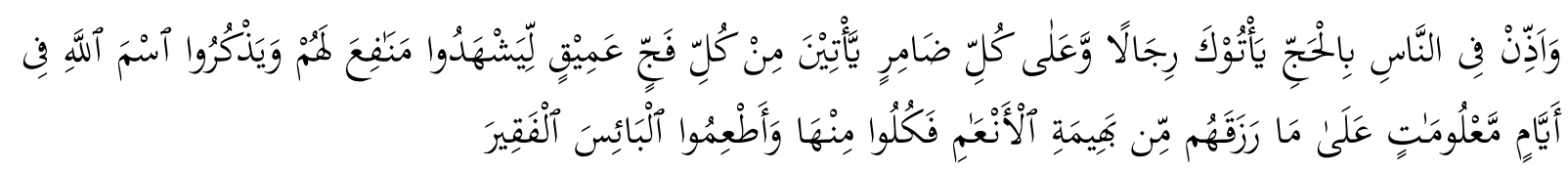

"Call (all) people to the pilgrimage. They will come to you on foot and every lean camel from every distant path, so they may obtain the benefits (in-store) for them and pronounce the Name of Allah on appointed days over the sacrificial animals He has provided for them. So eat from their meat and feed the desperately poor." (QS Al-Hāj): 27-28)

It is needed to be stressed to the students that within the enjoyment in doing pilgrimage are as the followings:

a. To have the awareness that humanity is on the journey towards Allah requires the purification of self and facing hardships that also require patience.

b. In practicing pilgrimage, humanity will better understand the love of Allah and the others and feel that they are nothing compared to the universe.

c. An adequately practiced pilgrimage will strengthen faith because it traces back the struggle of Islamic $d a^{\prime} w a h$ by Rasulullah and his companions in Makkah and Madinah.

Through pilgrimage, humanity will be made aware of the essence (haqiqah) of living, and Muslims shall not feel any differences between tribes, races, status, except the quality of their righteousness.

\section{CONCLUSION}

Based on the discussion in this article, the authors may conclude that Quranic Multiple Intelligences that may be applied in the educational institutions could be done through:

1. Spiritual approach. The steps are as follows: strengthening faith, piety (taqwā), prayers, and accustoming dzikr.

2. Practical approach. The steps are as follows: championing the Quran, establishing prayers (Șalat), practicing fasting, sharing wealth to the rightful, prospering the mosque, living the night with prayers, learning knowledge, voyaging in the educational trips, and accomplishing pilgrimage.

Furthermore, to achieve Quranic Multiple Intelligences optimally, these are some recommendations that need to be laid out: 
1. The educational institutions shall develop their learning method according to the need that keeps on developing.

2. Every new finding in scientific fields, especially relating to multiple intelligences, should be absorbed by the educational institutions, thus being implemented after adapting to the current condition and situation.

3. It is time for the Islamic educational institutions to make the Quran the primary resource in learning. Not only as reading material without its meaning being understood.

4. The educational institutions shall increase their learning strategy with multiple intelligences, especially with the primary references from the Quran.

5. The teachers in Islamic educational institutions shall be encouraged to practice learning strategies with multiple intelligences, thus developing them creatively, effectively, and innovatively.

6. The educational institutions shall actively delve into new inspirations on learning methods from the Quran. Continuous research on multiple intelligences is also essential to explore other aspects which have not been found in this research.

\section{Funding and Conflicts of Interest}

This research did not receive any specific grant from funding agencies and author's team declares that there is no conflict of interest for this research.

\section{REFERENCES}

Arikunto, S. (1990). Prosedur Penelitian: Suatu Pendekatan Praktek. Jakarta: Rineka Cipta.

Arif, M. (2021). The concept of Ali Abdul Halim Mahmud's Quranic Education: A critical analysis of 'fundamentalist' exegesis paradigm. Pertanika Journal of Social Sciences and Humanities, 28(4), 3391-3406. Retrieve from http://pertanika2.upm.edu.my/resources/files/Pertanika\%20PAPERS/ISSH\%20Vol.\%2028 \%20(4)\%20Dec.\%202020/49\%20JSSH-5509-2019.pdf

Arif, Z., Abdurrahman, A., \& Zulfitria, Z. (2021). Kosa Kata Kebaikan dalam Al Quran:(Analisis Makna Kata al-Khair, al-Tayyib, dan al-Hasanah). Al-I'jaz: Jurnal Studi Al-Qur'an, Falsafah dan Keislaman, 3(1), 98-112. Retrieve from http://jurnal.stiqsi.ac.id/index.php/AlIJaz/article/download/49/47

Armstrong, T. (2004). Sekolah Para Juara: Menerapkan Multiple Intelligences di Dunia Pendidikan. Bandung: Kaifa. Retrieve from https://onesearch.id/Record/IOS2862.UNMAL000000000026210

Baharuddin. (2007). Paradigma Psikologi Islami: Studi tentang Elemen Psikologi dari Al-Quran. Yogyakarta: Pustaka Pelajar.

Efendi, A. (2005). Revolusi Kecerdasan Abad 21. Bandung: Alfabeta.

Faisol, S. (1992). Format-Format Penelitian Sosial. Jakarta: Rajawali Press.

Gardner, H. (2013). Multiple intelligences (Kecerdasan Majemuk): Teori dalam Praktik. Tangerang: Interaksara.

Hadi, S. (1995). Metodologi Research. Yogyakarta: Andi Offset.

Hernowo dan Nurdin, C. (2004). Bu Slim dan Pak Bil: Kisah tentang Kiprah Guru "Multiple intelligences" di Sekolah. Bandung: MLC.

Husnaini, M., Fuady, A. S., \& Victorynie, I. (2020). Multiple Intelligence in the Perspective of the Qur'an. Indonesian Journal of Islamic Education Studies (IJIES), 3(2), 141-159. Retrieve from https://ejournal.iai-tribakti.ac.id/index.php/ijies/article/download/1358/801

Ilyas, Y. (2019). Kuliah Ulumul Qur'an. Yogyakarta: ITQAN Publishing.

Ilyas, Y. (2020). Kuliah Akhlaq. Yogyakarta: Suara Muhammadiyah. 
Kementerian Agama RI dan Pemerintah KSA. Al-Quran dan Terjemahnya. Tanpa Tahun.

Kisworo, B. (2017). Ibadah Haji Ditinjau Dari Berbagai Aspek. Al-Istinbath: Jurnal Hukum Islam, 2(1), 75-98. Retrieve from http://journal.iaincurup.ac.id/index.php/alistinbath/article/download/194/201

Madjid, N. (2007). 30 Sajian Ruhani: Renungan di Bulan Ramadlan. Bandung: Penerbit Mizan.

Muhadjir, N, (2000). Metodologi Penelitian Kualitatif. Yogyakarta: Penerbit Rake Sarasin.

Munawar-Rachman, B. (1995). Kontekstualisasi Doktrin Islam dalam Sejarah. Jakarta: Paramadina.

Mustofa, A. (2004). Scientific Fasting: Untuk Apa Berpuasa? Sidoarjo: PADMA Press.

Moleong, L. J. (2003). Metodologi Penelitian Kualitatif. Bandung: Remaja Rosdakarya.

Nata, A. (2002). Metodologi Studi Islam. Jakarta: RajaGrafindo Persada.

Nugroho, A. (2004). Rekonstruksi Kecerdasan Muslim: Mengaktifkan Kecerdasan Ruhani, Sosial, dan Akademik Seorang Muslim. Yogyakarta: Pustaka Salma.

Pasiak, T. (2008). Revolusi IQ/EQ/SQ: Menyingkap Rahasia Kecerdasan Berdasarkan Al-Quran dan Neurosains Mutakhir. Bandung: Penerbit Mizan.

Republika. (2009, February 5). "Isyarat-Isyarat IQ, EQ, dan SQ dalam Al-Qur'an". Retrieved from www.republika.co.id/berita/ensiklopedia-islam/tasauf/09/02/05/29676-isyarat-isyaratiq-eq-dan-sq-dalam-al-qur-an

Sensa, M. D. (2005). Quranic Quotient: Kecerdasan-Kecerdasan Bentukan Al-Quran. Jakarta: Penerbit Hikmah.

Shihab, M. Q. (2013). Kaidah Tafsir: Syarat, Ketentuan, dan Aturan yang Patut Anda Ketahui dalam Memahami Ayat-Ayat Al-Qur'an. Tangerang: Lentera Hati.

Siskawati, E., \& Surya, F. (2016). Bagaimana Masjid dan Masyarakat Saling Memakmurkan? Pemaknaan Akuntabilitas Masjid. Jurnal Akuntansi Multiparadigma, 7.

Suryana. (2009). Kewirausahaan Pedoman Praktis: Kiat dan Proses Menuju Sukses. Jakarta: Penerbit Salemba Empat.

Thalib, M. (2012). Al-Quran Tarjamah Tafsiriyah: Memahami Makna Al-Quran Lebih Mudah, Cepat, dan Tepat. Yogyakarta: Penerbit Ma'had An-Nabawy.

Wahid, S. A. (2011). Studi Ulang Ilmu Al-Qur'an \& Ilmu Tafsir. Yogyakarta: Suara Muhammadiyah. Retrieved from https://opac.perpusnas.go.id/DetailOpac.aspx?id=156512

Yasin, M. (2014). The concept of dhikr according to Al-Ghazali and its psychologycal benefit (Doctoral dissertation, IAIN Walisongo). Retrieved from http://eprints.walisongo.ac.id/2852/3/094411049 Bab2.pdf 